\title{
Scintigraphic study of the splenic circulation in rats
}

\section{Estudo cintilográfico da circulação esplênica em ratos}

\author{
Fábio Gontijo Rodrigues'; Andy Petroianu-TCBC-MG²; Simone Odília Fernandes Diniz³; Valbert Nascimento Cardoso33; Eduardo \\ VILHena de PARReIRA ${ }^{3}$
}

\section{A B S T R A C T}

\begin{abstract}
Objective: To evaluate the splenic parenchymal blood distribution through scintigraphic study. Methods: Thirty Wistar rats were randomly divided into six groups $(n=5)$. Group 1 (spleen - 30 minutes) and Group 2 (spleen - 90 minutes) underwent laparotomy with direction of blood flow to the spleen by ligature of the aorta near the iliac bifurcation and splanchnic vessels, keeping blood flow only in the splenic artery; Group 3 (spleen and stomach - 30 minutes) and Group 4 (spleen and stomach - 90 minutes) underwent laparotomy with direction of blood flow to the spleen and stomach by ligature of the aorta near the iliac bifurcation and splanchnic vessels, maintaining the flow through the splenic, gastric and splenogastric vessels; Group 5 (control - 30 minutes) and Group 6 (control - 90 minutes) underwent laparotomy and ligation of the aorta near the iliac bifurcation, keeping the flow to the abdominal organs. After arterial ligation, the animals received an injection of $0.2 \mathrm{ml}$ of sodium pertechnetate in the aorta. Scintigraphic images were taken and the animals had their spleens removed for radioactivity counting with an automatic counter device. Results: There was no difference in the amounts of radiation from the spleen between groups, indicating retention of the radioisotope by the spleen, even after the period of 90 minutes. Conclusion: The blood flow through the spleen is not continuous. The blood diffuses through the splenic parenchyma and its venous drainage is slow, not following a predictable sequence.
\end{abstract}

Key words: Spleen/Blood supply. Microcirculation. Splanchnic circulation. Radionuclide imaging. Rats.

\section{INTRODUCTION}

$\mathrm{T}^{\mathrm{n}}$ he blood flow of the human spleen is about 350 liters per day. Its irrigation is the by splenic artery, the splenogastric ateries and through collateral vessels, which include polar arteries, pancreatic arteries and left gastroomental artery. The splenic artery originates various pancreatic branches and the left gastro-omental artery before dividing in two (84\% -90\%) or three (10\% -16\%) lobar and segmental arteries of the spleen ${ }^{1,2}$. There are two branches of the splenic artery which supply the upper or cranial pole and the lower or caudal pole of the spleen. Venous drainage is made by the union of venous tributaries leaving the spleen to form the splenic vein. The spleen venous distribution follows the same pattern of the arterial supply. The splenic vein joins the superior mesenteric vein to form the portal vein ${ }^{3}$. The vascularization and anatomical distribution of abdominal organs in rats are similar to those found in humans.

In all mammals the splenic tissue is divided into two pulps. The white pulp consists of accumulation of lymphocytes, which follow the arteries, after leaving the trabeculae. The red pulp is formed by strings of macrophages and leukocytes, called splenic cords of Billroth, and venous sinuses. Within the spleen, arteries follow the trabeculae as trabecular arteries. Upon leaving the trabeculae, the arteries are surrounded by the white pulp in the form of a lymphocytes sheath (periarterial lymphatic sheat - PALS) ${ }^{4-10}$.

The artery that runs through the splenic parenchyma surrounded by PALS is called the follicular artery. Arteriolar branches come out of this artery and end in the perifollicular zone. By splitting at the white pulp, the follicular artery loses its sheath, originating many arterioles in a manner similar to a brush, being therefore called penicilate arterioles. These arterioles penetrate the red pulp and can present themselves surrounded by a sheath of macrophages, called Schweigger-Seidel sheath or ellipsoids 11. Between the white and red pulps is located the perifollicular zone, where reactions against antigens take place through open circulation, in which blood comes in contact with the spleen cells, initiating the immune reactions. The splenic microcirculation and the dynamics of cell movement are not yet fully understood ${ }^{12}$.

The scintigraphic evaluation of the spleen has been replaced by Doppler ultrasound, computed

1. Post-Graduation Program, Sciences Applied to Surgery and Ophthalmology, Faculty of Medicine, Federal University of Minas Gerais - UFMG, Belo Horizonte, Minas Gerais Satete - MG, Brazil; 2. Department of Surgery, Faculty of Medicine, UFMG; 3. Department of Clinical and Toxicological Analyses (Laboratory of Radioisotopes), Faculty of Pharmacy, UFMG. 
tomography and magnetic resonance imaging. However, scintigraphy is also important for the functional assessment of the spleen, since most studies are based on the removal of colloidal particles labeled with radionuclides by splenic macrophages. Among the radiopharmaceuticals, the most used to study the spleen is the sulfur colloid labeled with 99 meta-Technetium (99mTc). Other colloids used for the spleen studies are sodium phytate and tin 13,14.

Even being more intensely being captured by the liver, phytate is used in the study of the spleen due to its ease of preparation. When one needs to get splenic images without interference of the liver, one can use autologous erythrocytes labeled with $99 \mathrm{mTc}$-sulfur colloid ${ }^{15}$. This technique is less adopted, being more laborious. Radiolabeled bacteria can also be used in scintigraphic studies ${ }^{16}$. The function of operated spleens was investigated in a study that evaluated the phagocytosis of Escherichia coli labeled with $99 \mathrm{mTc}^{5}$

Another radioisotope used in scintigraphic studies is sodium pertechnetate $\left(\mathrm{Na}^{99 \mathrm{~m}} \mathrm{TcO}_{4}\right.$, which is obtained by elution of $99 \mathrm{~m}$ Tc in saline. The sodium pertechnetate has a short half-life - about six hours - and its gamma energy emission with $140 \mathrm{KeV}$ makes it suitable for scintigraphic study of organs ${ }^{17,18}$. Since it is a saline solution, it does not suffer opsonization, nor is phagocytosed by cells of the mononuclear phagocyte system. The molecule of the radioisotope is also inert to the action of the cells of organic defense, so the behavior of this radiopharmaceutical is one of an aqueous iso-osmolar liquid diluted in blood without antigenicity.

The spleen is the only organ whose circulation is still not adequately understood. The aim of this study was, through a scintigraphic study, to evaluate the spleen parenchymal blood flow, regarding blood input and output

\section{METHODS}

This work was performed in accordance with the recommendations of the International Standards for the Protection of Animals, the Brazilian Code of Animal Experimentation and Ethics Committee on Animal Experimentation of UFMG / CETEA, having been approved by this division ${ }^{19,20,21}$.

We randomly assigned 30 rats to six groups $(n=$ 5): Group 1 - control, 30 minutes: laparotomy and ligation of the aorta proximal to the bifurcation of the iliac arteries and intra-aortic injection of sodium pertechnetate. The animals were sacrificed after 30 minutes and subjected to splenectomy; Group 2 - control, 90 minutes: laparotomy and ligation of the aorta proximal to the bifurcation of the iliac arteries, and intra-aortic injection of sodium pertechnetate. The animals were sacrificed after 90 minutes and underwent splenectomy; Group 3 - spleen, 30 minutes: laparotomy and ligation of the aorta proximal to the iliac bifurcation and its visceral branches arteries, with preservation of the splenic artery, to conduct the flow of sodium pertechnetate injected towards the spleen. The animals were sacrificed after 30 minutes and underwent splenectomy; Group 4 - spleen, 90 minutes: laparotomy and ligation of the aorta proximal to the bifurcation of the iliac arteries and its visceral branches, with the preservation of the splenic artery to conduct the flow of sodium pertechnetate injected towards the spleen. The animals were sacrificed after 90 minutes and underwent splenectomy; Group 5 - spleen and stomach, 30 minutes: rats underwent laparotomy and ligation of the aorta proximal to the iliac bifurcation and its visceral branches, with preservation of the splenic and gastric arteries to direct the flow of sodium pertechnetate to the spleen and stomach. Splenogastric vessels were kept. The animals were sacrificed after 30 minutes and underwent splenectomy; Group 6 spleen and stomach, 90 minutes: laparotomy and ligation of the aorta proximal to the iliac bifurcation and its visceral branches, with preservation of the splenic and gastric arteries to direct the flow of sodium pertechnetate to the spleen and stomach. Splenogastric vessels were kept. The animals were sacrificed after 90 minutes and underwent splenectomy.

After the arterial ligations, the animals received an injection of $0.2 \mathrm{ml}$ of sodium pertechnetate in the aorta. Technetium was diluted in sterile saline to contain approximately $200 \mathrm{iCi}$ activity in $0.2 \mathrm{ml}$ of solution. In a $1 \mathrm{ml}$ syringe, we prepared the radiopharmaceutical solution in $0.2 \mathrm{ml}$ as the standard dose, so that the radioactive decay as a function of time could be taken into account in the final evaluation.

After the injection of radioactive material, the scintigraphic study began, through the gamma camera. We then made still images, with vesting period of five minutes. The images were taken immediately after the injection of $0.2 \mathrm{ml}$ of radioactive solution in the aorta of each rat and after ten, 20 and 90 minutes.

After the collection of images in the gamma camera (30 minutes or 90 minutes), we ligated the splenic vascular pedicle and the spleen was removed for radioactive counting. The animals were killed by overdose of anesthetic (200 mg / kg ketamine +25 mg / kg xylazine injected into the peritoneum).

The removed spleens had their radioactivity measured with an automatic counter device. We also measured the radioactivity of the syringe prepared as standard dose. The radiation was expressed as counts per minute (cpm), as percentage of injected dose per gram of spleen ( $\%$ ID / g). The results were obtained by dividing the radiation measured in the spleen by the total measured at the standard dose, and dividing that result by the weight of the spleen. To compare the weights of the rats, the Mann-Whitney test was applied. Data were presented as mean, median, standard error of the mean, minimum and maximum values. 
In this study three surgical procedures and evaluations were carried out in two stages (30 and 90 minutes); thus, there were six combinations, and for each combination five replicates were obtained. This therefore configured a factorial experiment, with analysis using generalized linear model. The three surgical procedures (control group, spleen, spleen and stomach) and times of injection were found on the variable percentage of injected dose per gram (\% ID / g), besides the variable injected sodium pertechnetate. We also evaluated the existence of an interaction effect between the type of procedure and the follow-up time. We considered the level of $p<0.05$ for significance of differences between the groups regarding the variables studied.

\section{RESULTS}

All animals tolerated the anesthesia, without complications during the study time for each group. The rats had their weight measured and the comparison of average weight between the groups showed no difference $(p=0.106)$. No difference was found between the groups in the amount of injected sodium pertechnetate (ADM), nor in relation to the percentage of injected dose per gram (\% ID / g), nor in the times studied (30 and 90 minutes) (Figure 1 and table 1).

The scintigraphic images obtained in this study qualitatively revealed the uptake of the radioactive drug by region of the spleen and stomach. A comparison of the images obtained at different times of the study indicated that there was a decrease in radioactivity in the central thoracoabdominal region after 90 minutes, while maintaining the uptake of the radioisotope in the area of stomach and spleen. The images relate mainly to the stomach due to its affinity for sodium pertechnetate. The thyroid also captured the radiopharmaceutical, with better visualization after 90 minutes. Figures 2, 3 and 4 show the images obtained in rats after 30 and 90 minutes, with a concentration of radioisotope in the abdominal region of the spleen and stomach, as well as uptake by the thyroid after 90 minutes. During this period, there was distribution of the radioactive material, once concentrated in the thoracoabdominal region, with residence in the stomach and thyroid gland, both well contrasted. Even in the group

Table 1 - $\quad p$ values for the variables $\%$ ID/g and injected sodium pertechnetate by the generalized linear model.

\begin{tabular}{lcc}
\hline Parameters & \% ID/g & Injected \\
\hline Type of operation & 0.990 & 0.722 \\
Time (30 or 90 minutes) & 0.166 & 0.636 \\
Type of operation + time & 0.991 & 0.672 \\
\hline
\end{tabular}

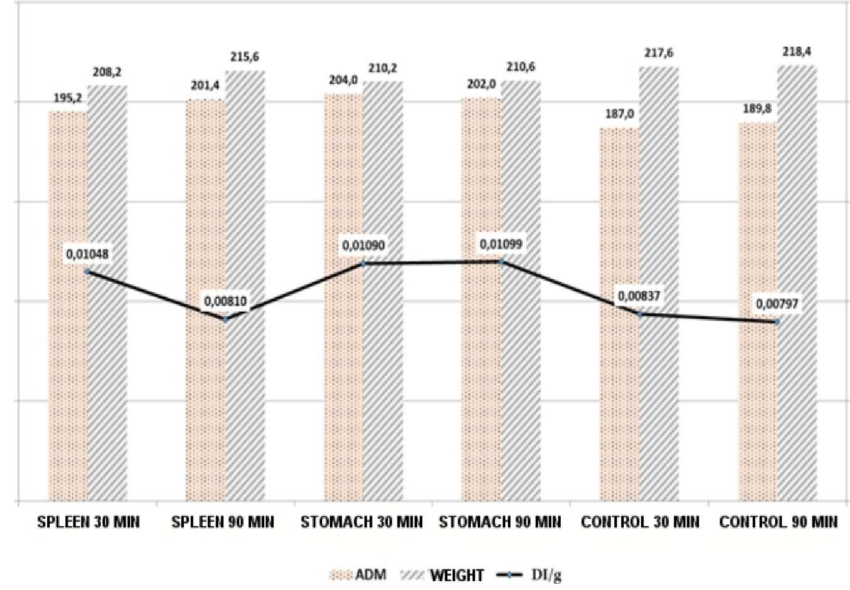

Figure 1 - Comparison between the mean values of injected sodium pertechnetate (ADM), weight and radiation measured in the spleen (\% ID / g) of the groups studied.

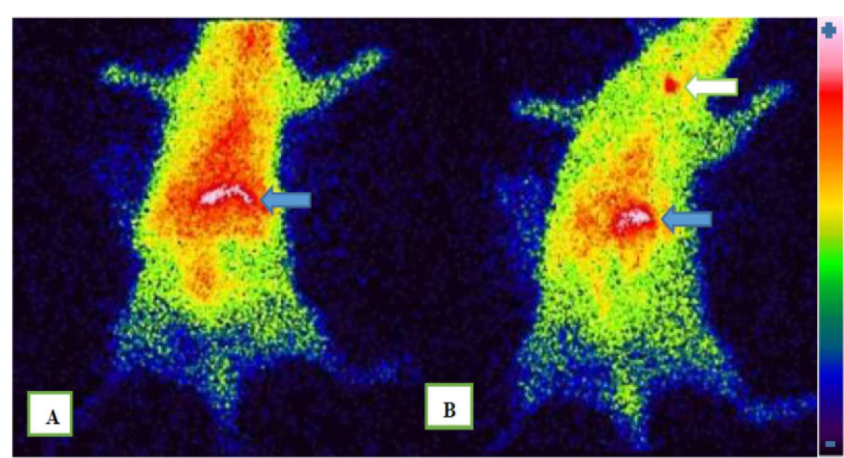

Figure 2 - Scintigraphy mouse spleen group 2 - 90 minutes.

A) image obtained 20 minutes after injection of sodium pertechnetate, with concentration of the radioisotope in the spleen and stomach region (blue arrow); B) image obtained 90 minutes after the injection of pertechnetate, with concentration of the radioisotope in the region of the spleen and stomach (blue arrow) and uptake by the thyroid gland (white arrow). Decreased radioactivity in the central thoracoabdominal region.

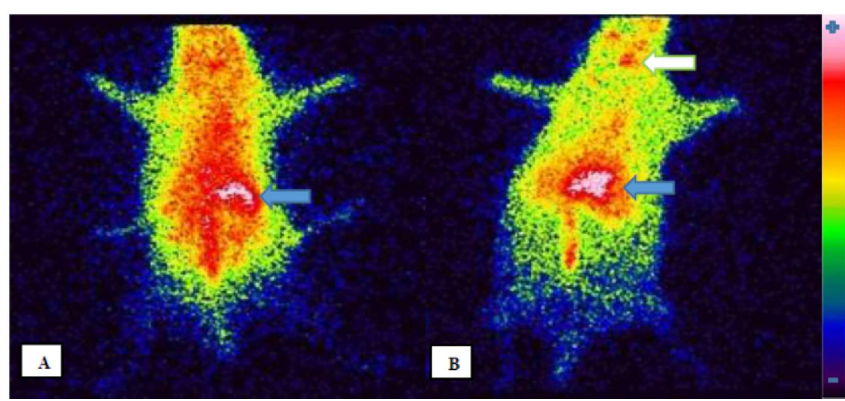

Figure 3 - Images obtained in rats of the stomach and spleen (30 and 90 minutes) groups.

A) Image of rat 1 from the stomach and spleen group - 30 minutes: 20 minutes after injection of sodium pertechnetate, with the highest concentration of radioisotope in the abdominal region (stomach and spleen - blue arrow); B) Image of rat 2 of the spleen and stomach group - 90 minutes: after 90 minutes into the injection of radioisotope, showing uptake in the abdominal region (stomach and spleen) and also by the thyroid gland (white arrow). Decreased radioactivity in the central thoracoabdominal region. 


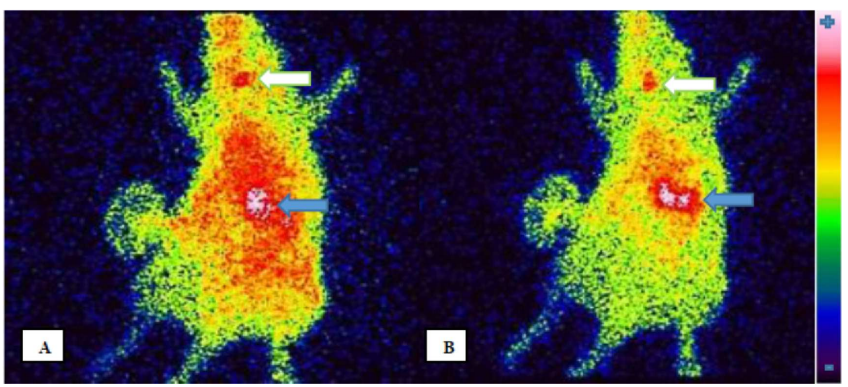

Figure 4 - Image obtained from rat 3 in the control group - 90 minutes.

In both there is radioisotope uptake in the abdominal region (stomach and spleen) and in the thyroid gland (arrows). A) 20 minutes after injection of the radioisotope; B) 90 minutes after the injection of the radioisotope. Decreased radioactivity in the central thoracoabdominal region.

in which th the left gastric artery and splenogastric vessels were ligated, there was a concentration of the radiopharmaceutical in the gastric region, indicating that irrigation from the chest and esophagus led the sodium pertechnetate to the stomach.

\section{DISCUSSION}

This work is part of a line of research on the spleen. Its relevance is resides in the lack of knowledge of the the path of parenchymal circulation of this organ. Studies on the anatomy and splenic operations used findings from animals merged to humans' $4-10,22$. Although there are differences in the anatomy and physiology of the spleen between species, the knowledge gained in animal studies may assist in research on humans.

The rat was chosen for this study due to its size, ease of handling and availability. The gamma camera and automatic gamma counter used were consistent with the size of the rats and their spleens.

The choice of adult animals was based on data that showed the difference between the functions of the spleen in adulthood and the age extremes, whereas anatomical and circulation changes could also occur during the life of the animals ${ }^{6}$. We used only females to standardize the groups and remove potential confounding factors.

There are studies using rats, both in experimental studies of the spleen and with radioisotopes, indicating that the model is appropriate for this investigation. Steiniger et al. found anatomical differences between the spleens of humans and rats, describing structural variations in the cellular composition of the perifollicular white and red pulp zone ${ }^{22}$. There are differences in cellular activity even among compartments of the same organ. Matsuno, Fujii and Kotani stressed that in rats the macrophages of the splenic red pulp exhibited intense phagocytic activity to carbon particles, whereas macrophages of the perifollicular zone showed a decreased phagocytic activity of the same particles, being, however, responsible for phagocytosis of polysaccharides ${ }^{23}$. The clarifying of the intraparenchymal circulation can help in understanding the functions and cell dynamics within the spleen. Other studies using radioisotopes and radiation counters appliances suh as ours expressed their results as a percentage of injected dose per gram (\% ID / g) of the organ or tissue evaluated ${ }^{17,24}$

The arterial ligations were performed in order to direct the blood flow and the radioisotope injected into the spleen. With the injection of radioactive material towards the spleen, it was possible to assess the initial distribution (30 minutes), the late (90 minutes) one and also the elimination of the drug. The "stomach and spleen" (30 and 90 minutes) groups had sustained flow from the left gastric artery and the splenogastric vessels. The maintenance of these vessels could influence the arrival of radioisotope at the spleen and also its elimination. The flow through the splenogastric vessels seems to occur mainly from the stomach to spleen, as proven by segmental ischemia of the spleen, described after ligatures of the splenogastric vessels 25,26 . The injection of sodium pertechnetate directly into the splenic artery was not possible in the rat due to the small caliber of this vessel.

The values of pertechnetate injected doses displayed no difference when compared, being worth noting that the groups were homogeneous regarding the administered radiation. The dose of $200 \mathrm{iCi}$, equivalent to 7.4MBq, has been used in other studies with rats, being suitable for this animal model 18,27 .

No difference was found in the amount of radiation present in the spleen when comparing the types of operation, including the control groups, in which all the splanchnic circulation was maintained. One possible explanation may be the circulation of sodium pertechnetate$99 \mathrm{mTc}$ to other organs, being retained when reaching the spleen. An experimental study that evaluated the biodistribution of sodium pertechnetate by various organs of rats undergoing duodenal switch indicated increased uptake by the spleen of operated rats, without, however, having found the causes for such findings 24 .

Another study that evaluated the uptake of sodium pertechnetate by rats' spleens, after conducting electroacupuncture at various frequencies, obtained higher splenic uptake in groups undergoing the procedure when compared to control ones ${ }^{27}$. Another possible explanation is the amount of injected sodium pertechnetate, that may have been enough to impregnate the spleen, even in the group in which the flow was not directed to that organ. One limitation of the applied operative techniques is that the branches of the thoracic aorta could not be ligated, as well as the posterior branches and lumbar arteries, not obtaining a flow exclusive to the spleen.

The comparison of radiation contained in the spleen at different times (30 and 90 minutes) between groups undergoing the same surgical procedure also showed no difference, indicating there was no elimination of the 
radiopharmaceutical contained in the spleen. This finding is consistent with the hypothesis that the parenchymal circulation does not leave the spleen immediately, but depends on still unknown factors.

The predominantly open circulation of the spleen may explain the retention of blood in the splenic parenchyma. Most studies on the splenic microcirculation uses the injection of materials that, when distributing through the vessels of the splenic parenchyma, reveal the followed path. Robinson injected oils, bitumen diluted in turpentine, pigments and gelatins to attempt to delineate the vasculature inside the spleen of dogs. This author considered gelatin dye the best material, and identified the output of this gelatin by the ellipsoids, with distribution in all directions in the red pulp before reaching the venous circulation, reinforcing the dominance of the splenic circulation of open type ${ }^{11}$.

Chen injected plastic microspheres to study the splenic circulation of rabbits and observed that the two types of circulation coexisted in the spleen, with $90 \%$ of the blood flowing through open circulation ${ }^{12}$. Another study showed the presence of intra-endothelial "cracks", allowing the output elements of sinusoids toward the pulp ${ }^{28}$.

In this study, sodium pertechnetate was chosen for not being a radiolabeled colloid, nor a material with antigenic particles. The spleen removes such markers by phagocytosis. Contrary to what is observed in the stomach and thyroid, no specific affinity of spleen with sodium pertechnetate has been described. This model examined the splenic circulation through a substance flowing as an aqueous solution, without particles or characteristics which promote its retention in spleen cells. Therefore, the flow of the pertechnetate solution is parenchymal.

It is possible that there is affinity of the spleen with the radioisotope used and that its retention is given by a yet unknown mechanism. However, the affinity and the use of this radioisotope in scintigraphy are established. The mechanism of uptake of pertechnetate is the formation of the anion $99 \mathrm{mTcO}_{4}$, which is captured by the sodium-iodide symporter (NIS) - a transmembrane glycoprotein that actively transports anions to the interior of cells (as in the thyroid follicular cells) ${ }^{29}$. The organs with greater expressions of this glycoprotein are thyroid, stomach and salivary glands. Research with rats showed low uptake and rapid decay of pertechnetate in the spleen due to the low expression of NIS ${ }^{30}$. The low expression of NIS by the spleen can enhance the hypothesis of retention by circulatory mechanisms formulated in this investigation.

As for the scintigraphic images obtained, we carried out only qualitative analysis. We opted for the non-quantitative analysis, through the selection of regions of interest (ROI) because the stomach is avid for the sodium pertechnetate and its accumulation in that organ may indicate a false retention in the spleen due to their proximity. Even in groups where of the left gastric artery and splenogastric vessels were ligated, the stomach was contrasted by pertechnetate, probably through anastomoses between the arterial branches that nourish the distal esophagus and the stomach. The direct counting of radiation on the organ after splenectomy was more accurate in the final evaluation.

In conclusion, the blood flow through the spleen is not continuous. The blood diffuses through the splenic parenchyma and its venous drainage is slow, not following a predictable sequence.

\section{Acknowledgements} financial support.
The authors thank FAPEMIG and CNPq for

\title{
R E S U M O
}

\begin{abstract}
Objetivo: avaliar a distribuição sanguínea vasculoparenquimatosa do baço, por meio de estudo cintilográfico. Métodos: trinta ratos da raça Wistar foram distribuídos aleatoriamente em seis grupos ( $n=5$ ). Grupo 1 (baço - 30 minutos) e Grupo 2 (baço - 90 minutos): submetidos à laparotomia com direcionamento do fluxo sanguíneo para o baço, por meio de ligadura da aorta próxima à bifurcação das ilíacas e dos vasos esplâncnicos, mantendo apenas a artéria esplênica; Grupo 3 (baço e estômago - 30 minutos) e Grupo 4 (baço e estômago - 90 minutos): submetidos à laparotomia com direcionamento do fluxo sanguíneo para baço e estômago, por meio de ligadura da aorta próxima da bifurcação das ilíacas e dos vasos esplâncnicos, com manutenção do fluxo pelas artérias esplênica, gástrica e vasos esplenogástricos; Grupo 5 (controle - 30 minutos) e Grupo 6 (controle - 90 minutos): submetidos à laparotomia e ligadura da aorta próxima à bifurcação das ilíacas, mantendo o fluxo para os órgãos abdominais. Após as ligaduras arteriais, os animais receberam injeção de 0,2ml de pertecnetato de sódio na aorta. Foram realizadas imagens cintilográficas, e os animais tiveram o baço retirado para contagem radioativa em aparelho contador automático. Resultados: não houve diferença nos valores de radiação do baço entre os grupos, indicando retenção do radioisótopo pelo baço, mesmo após o período de 90 minutos. Conclusão: o fluxo sanguíneo através do baço não é contínuo. O sangue difunde-se pelo parênquima esplênico e sua drenagem venosa é lenta, não seguindo sequência previsível.
\end{abstract}

Descritores: Baço/Irrigação sanguínea. Microcirculação. Circulação esplâncnica. Cintilografia. Ratos. 


\section{REFERENCES}

1. Cortés JA, Gómez Pellico L. Arterial segmentation in the spleen. Surg Radiol Anat. 1988;10(4):323-32.

2. Gupta CD, Gupta SC, Arora AK, Singh PJ. Vascular segments in human spleen. J Anat. 1976;121(Pt 3):613-6.

3. Skandalakis PN, Colborn GL, Skandalakis LJ, Richardson DD, Mitchell WE Jr, Skandalakis JE. The surgical anatomy of the spleen. Surg Clin North Am. 1993;73(4):747-68.

4. Elmore SA. Enhanced histopathology of the spleen. Toxicol Pathol. 2006;34(5):648-55.

5. Marques RG, Petroianu A, Coelho JM. Bacterial phagocytosis by macrophage of autogenous splenic implant. Braz J Biol. 2003;63(3):491-5

6. Petroianu A. Estudo quantitativo da função fagocitária de macrófagos em baços íntegros e em remanescentes de esplenectomia subtotal, em mamíferos. [Tese de livre docência. Disciplina de Gastroenterologia Cirúrgica - Departamento de Cirurgia, Ortopedia e Traumatologia]. Ribeirão Preto/SP: Universidade de São Paulo, Faculdade de Medicina de Ribeirão Preto; 1993

7. Petroianu A, Veloso DF, Alberti LR, de Souza Vasconcellos L. Plasma lipid alterations after total splenectomy, subtotal splenectomy and splenic auto-implants in rats. J Gastroenterol Hepatol. 2008;23(7 Pt 2):e221-4.

8. Petroianu A, Pereira TC, Oliveira TAN, Barbosa AJA. Avaliação de diferentes métodos de conservação esplênica para tratar lesão cortante do baço em cão. Rev Col Bras Cir. 2004;31(6):364-7.

9. Alberti LR, Rocha RF, Caldeira DAM, Petroianu A. Análise de sobrevivência relacionada ao sexo, após esplenectomia, em modelo animal. Rev Bras Hematol Hemoter. 2007;29(2):119-22.

10. Caldeira DAM, Rocha RF, Alberti LR, Petroianu A. Influência da esplenectomia na capacidade física em ratos. Rev Bras Hematol Hemoter. 2005;27(3):197-200.

11. Robinson WL. The vascular mecanism of the spleen. Am J Pathol. 1926;2(5):341-56

12. Chen LT. Microcirculation of the spleen: an open or closed circulation? Science. 1978;201(4351):157-9.

13. Ehrlich CP, Papanicolaou N, Treves S, Hurwitz RA, Richards P. Splenic scintigraphy using Tc-99m-labeled heat-denatured red blood cells in pediatric patients: concise communication. J Nucl Med. 1982;23(3):209-13

14. Phom H, Kumar A, Tripathi M, Chandrashekar N, Choudhry VP, Malhotra A, et al. Comparative evaluation of Tc-99m-heatdenatured RBC and TC-99m-anti-D IgG opsonized RBC spleen planar and SPECT scintigraphy in the detection of acessory spleen in postsplenectomy patients with chronic idiopathic thrombocytopenic purpura. Clin Nucl Med. 2004;29(7):403-9.

15. Menth M, Herrmann K, Haug A, Raziorrouh B, Zachoval R, Jung $\mathrm{CM}$, et al. Intra-hepatic splenosis as an unexpected cause of a focal liver lesion in a patient with hepatites $C$ and liver cirrhosis: a case report. Cases J. 2009;2:8335.

16. Diniz SO, Resende BM, Nunan EA, Simal CJ, Cardoso VN. 99m Technetium labelled Escherichia coli. Appl Radiat Isot. 1999;51(1):336.

17. Chacon DA, Araújo-Filho I, Villarim-Neto A, Rêgo AC, Azevedo IM, Bernardo-Filho $\mathrm{M}$, et al. Biodistribution of the radiopharmaceutical

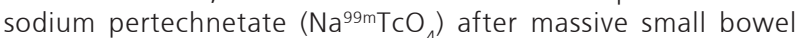
resection in rats. Acta Cir Bras. 2007:22(6):430-5.
18. Valenca SS, Lima EA, Dire GF, Bernardo-Filho M, Porto LC. Sodium pertechnetate $\left(\mathrm{Na}^{99 \mathrm{~m}} \mathrm{TCO}_{4}\right)$ biodistribution in mice exposed to cigarette smoke. BMC Nucl Med. 2005:5(1):1.

19. Petroianu A. Pesquisa experimental. In: Petroianu A, editor. Ética, Moral e Deontologia Médicas. Rio de Janeiro: Guanabara Koogan; 2000. p.185-90

20. Rollin $\mathrm{BE}$. The regulation of animal research and the emergence of animal ethics. Theor Med Bioeth. 2006;27(4):285-304.

21. Marques RG, Morales MM, Petroianu A. Brazilian law for scientific use of animals. Acta Cir Bras. 2009;24(1):69-74.

22. Steiniger B, Barth P, Herbst B, Hartnell A, Crocker PR. The speciesspecific structure of microanatomical compartments in the human spleen: strongly sialoadhesin-positive macrophages occur in the perifollicular zone, but not in the marginal zone. Immunology. 1997;92(2):307-16

23. Matsuno K, Fujii H, Kotani M. Splenic marginal-zone macrophages and marginal metallophils in rats and mice. Cell Tissue Res. 1986;246(2):263-9.

24. Araujo-Filho I, Rêgo ACM, Brandão-Neto J, Villarim-Neto A, Egito EST, Azevedo IM, et al. Biodistribution of the radiopharmaceutical sodium pertechnetate after biliopancreatic bypass with a duodenal switch. Braz arch biol technol. 2007;50:189-97.

25. Driessen C, Paulus GF, Robben SG, Tjon a Tem WE, Van den Neucker A, Verhoeven BH, et al. Splenic size after division of the short gastric vessels in Nissen fundoplication in children. Pediatr Surg Int. 2012;28(3):235-8.

26. Martinez DG, Sánchez AW, García AP. Splenic abscess after laparoscopic Nissen fundoplication: a consequence of short gastric vessel division. Surg Laparosc Endosc Percutan Tech. 2008;18(1):825 .

27. Senna-Fernandes $V$, França $D L$, Santos $K C$, Sousa RS, Silva $D$, Cortez CM, et al. Effect of Zusanli (ST.36) electroacupuncture at two frequencies on the bioavailability of $(99 \mathrm{~m}) \mathrm{Tc}$-sodium pertechnetate and on labeling of blood constituents in rats. J Acupunct Meridian Stud. 2009;2(2):135-46.

28. Weiss $L$. A scanning electron microscopic study of the spleen. Blood. 1974:43(5):665-91.

29. Boschi F, Pagliazzi M, Rossi B, Cecchini MP, Gorgoni G, Salgarello $M$, et al. Small-animal radionuclide luminescence imaging of thyroid and salivary glands with Tc99m-pertechnetate. J Biomed Opt. 2013;18(7):76005

30. Zuckier LS, Dohan O, Li Y, Chang CJ, Carrasco N, Dadachova E. Kinetics of perrhenate uptake and comparative biodistribution of perrhenate, pertechnetate, and iodide by Nal symporter-expressing tissues in vivo. J Nucl Med. 2004;45(3):500-7. Erratum in: J Nucl Med. 2004;45(4):558

Received on 20/10/2013

Accepted for publication 05/01/2014

Conflict of interest: none.

Source of funding: FAPEMIG and CNPq

Mailing address:

Fábio Rodrigues Gontijo

E-mail: fabiogontijo1@hotmail.com 